Article

\title{
The Increase in the Arsenic Concentration in Brown Rice Due to High Temperature during the Ripening Period and Its Reduction by Silicate Material Treatment
}

\author{
Protima Dhar ${ }^{1,2}$, Kazuhiro Kobayashi ${ }^{2}$ (®) Kazuhiro Ujiie ${ }^{2}$, Fumihiko Adachi ${ }^{2}$, Junko Kasuga ${ }^{2}$, \\ Ikuko Akahane ${ }^{3}$, Tomohito Arao ${ }^{4}$ and Shingo Matsumoto ${ }^{2, *}$ \\ 1 The United Graduate School of Agricultural Sciences, Tottori University, 101-4, Koyama-cho-minami, \\ Tottori 680-8550, Japan; protimadhar460@gmail.com \\ 2 Faculty of Life and Environmental Sciencees, Shimane University, 1060, Nishikawatsu-cho, \\ Matsue, Shimane 690-8504, Japan; kobayasi@life.shimane-u.ac.jp (K.K.); ujiiek@life.shimane-u.ac.jp (K.U.); \\ fadachi@life.shimane-u.ac.jp (F.A.); kasuga@life.shimane-u.ac.jp (J.K.) \\ 3 Institute for Agro-Environmental Science, National Agriculture and Food Research Organization, 3-1-3, \\ Kannondai, Tsukuba, Ibaraki 305-8604, Japan; redwing@affrc.go.jp \\ 4 National Agriculture and Food Research Organization; 2-1-18, Kannondai, Tsukuba Ibaraki 305-8666, Japan; \\ arao@affrc.go.jp \\ * Correspondence: smatsu@life.shimane-u.ac.jp; Tel.: +81-(853)-34-1824
}

Received: 8 June 2020; Accepted: 10 July 2020; Published: 12 July 2020

\begin{abstract}
We investigated the effect of temperature during the ripening period on the rice yield and arsenic (As) concentration in brown rice, using temperature gradient chambers (TGCs). Rice grown in Wagner pots (1/5000a) was placed in three TGCs (each TGC was set at four temperature levels: ambient, mildly-high temperature, moderately-high temperature, and super-high temperature) from one week after heading until harvest. In the TGCs, a range of mean air temperatures was observed in the range of $2{ }^{\circ} \mathrm{C}$ above the ambient temperature. There was a significant negative correlation between the brown rice yield and the air and soil temperatures, and the increase in air and soil temperatures resulted in a decrease in the yield. The reduction in yield was significantly mitigated by the application of calcium silicate. The concentration of As in the brown rice was significantly positively correlated with the air and soil temperature, and the concentration of As increased with increasing air and soil temperatures. When calcium silicate was applied, the concentration of As in brown rice was significantly lower at all temperature ranges, and its application was effective in reducing the arsenic concentration even at high temperatures. These results suggest that the application of silicate material may help mitigate the decrease in yield and the increasing As concentration in brown rice even under high-temperature conditions.
\end{abstract}

Keywords: arsenic; calcium silicate; dimethyl arsenic acid; high temperature; inorganic arsenic; rice; temperature gradient chamber

\section{Introduction}

The Fifth Assessment Report of the Intergovernmental Panel on Climate Change [1] states that "the observed global warming since the mid-20th century has a high probability of being anthropogenic more than 95\%". This trend of high temperatures is sure to continue, and there are global concerns about the impact of high temperatures on agricultural products. In paddy rice cultivation, in addition to the problems caused by climate change, high-temperature growth disturbances that significantly reduce the yield and quality of rice are frequent and problematic [2]. Peng et al. [3] directly proved that the 
increase in nighttime temperature due to global warming reduces the rice yield. Morita and Nakano [4] also reported that at temperatures above the optimum growing temperature, dry matter production is inhibited due to small grain size, lower maturity, lower grain quality, sterility, and consequently lower grain yield.

Against this background indicating that changes in temperature due to global warming may lead to a decrease in rice yield and quality, Arao et al. [5] analyzed the concentration of arsenic (As) in rice grains produced between 1995 and 2014, and their results showed a significant correlation between the concentration of As in rice and the daily mean temperature (DMT) between two and four weeks after the emergence of the rice in the year in which it was produced, suggesting that the higher the temperature during the rice ripening period, the higher the concentration of inorganic As (iAs) in the rice grains. The Codex Alimentarius Commission [6] established upper limits for the permissible concentration of iAs in milled and brown rice as $0.20 \mathrm{mg} \mathrm{kg}^{-1}$ and $0.35 \mathrm{mg} \mathrm{kg}^{-1}$, respectively.

Arsenic is widely distributed in nature, and it is contained in the soil at an average of $11 \mathrm{mg} \mathrm{kg}^{-1}$ [7]. Ferns, known as arsenic hyperaccumulators, show concentrations of up to 2 percent by dry weight [8]. However, it is known that most of the field crops do not generally show concentrations above $1 \mathrm{mg}$ $\mathrm{kg}^{-1}$ [9]. In contrast, stems and leaves of paddy rice can usually reach about $5 \mathrm{mg} \mathrm{kg}^{-1}$ even when grown in unpolluted soil [10]. The difference in the As concentration between many field crops and paddy rice is greatly influenced by the form of As species in their cultivated soil. Since the upland soil is oxidative, As exists as pentavalent arsenate and is strongly bound to iron and aluminum in the soil so that it is not eluted into the soil solution [11]. Therefore, many field crops do not readily absorb As. On the other hand, since paddy fields are in a reducing condition, As is easily reduced to highly soluble trivalent arsenite and is easily eluted into the soil solution so that paddy rice absorbs As easily [11]. When the As concentration was compared by parts, the highest concentration of As was found in the roots, followed by the stems and leaves, and the rice grain was the lowest [10]. For example, the concentration of As in rice grains grown in soil containing a high concentration of arsenic is unlikely to exceed $1 \mathrm{mg} \mathrm{kg}^{-1}$ [12]. Zavala and Duxbury [12] obtained rice produced or distributed around the world, and the variation in the concentration of As was investigated. They found a considerable variation of 0.005 to $0.710 \mathrm{mg} \mathrm{kg}^{-1}$ in total As concentration. Furthermore, they estimated that the normal concentration of As in rice in the world is in the range of 0.08 to $0.20 \mathrm{mg} \mathrm{kg}^{-1}$ by considering the literature values. Rice is a staple food for about half of the world's population, but it is also the most common source of iAs, a class 1 carcinogen [13]. It is essential to do research to clarify the mechanism of As accumulation in brown rice. It is known that there are various defense mechanisms when As is absorbed from the soil [14,15] and is transferred to brown rice [16]. In recent years, proteomic analysis and genetic analysis studies have been conducted on the As-trapping function in nodes [17]. As mentioned above, there is a concern that the As concentration in rice grains will increase due to the global temperature rise, and it will therefore be necessary to reduce the As concentration even in rice grown in uncontaminated soil.

A temperature gradient chamber (TGC) was designed to provide the appropriate technology to develop an experimental facility to study the response of rice to temperature stress and changes in the global environment [18]. The TGC is a highly effective system for studying the effects of temperature on crop cultivation because it allows for high-temperature treatment linked to the actual temperature. In paddy rice cultivation, it is necessary to investigate the effect of temperature on the As accumulation and speciation of rice grains in order to understand the effect of temperature increases on the rice yield and the As concentration. The present experiments were conducted on uncontaminated soil with relatively low As concentrations. Because rice grown in contaminated soils or soils with extremely high concentrations of As is very unlikely to be marketed, we thought it would be better for the evaluation of the actual production and distribution of rice and the safety of the food to conduct the experiments in average paddy soils where the As concentrations are not so high.

Many countermeasures to reduce the As concentration in rice have been reported, such as breeding varieties with low As absorption, water-saving cultivation, and the application of soil amendments 
to reduce the As absorption [19-21]. However, the breeding of low-absorption varieties requires an extended period. Water-saving cultivation is problematic in terms of reduced yield and quality as well as an accelerated absorption of cadmium. In contrast, the application of soil amendment is a practical measure for farmers because it is general manure management. We have shown that the application of silicic materials reduces the As concentration in brown rice [19,22,23], but it has not been established whether the silicic acid application can reduce the concentration of brown rice As even at high temperatures. We conducted the present study to clarify the relationship between the temperature and the concentration of As in brown rice by setting the temperature level after emergence with TGCs, and we investigated whether the silicic acid application is effective in reducing the concentration of As in brown rice even under the increased temperature.

\section{Materials and Methods}

\subsection{Soil Preparation, Si Material Treatment and Rice Cultivation}

For the rice cultivation, we filled Wagner pots (1/5000a, Fujiwara Scientific, Tokyo, Japan) with $3 \mathrm{~kg}$ of As-uncontaminated gray lowland paddy soil collected from the plowed layer of a paddy field at Matsue, Shimane, Japan. In every pot we mixed $2.8 \mathrm{~g}$ of a compound fertilizer that contained N $14 \%$, $\mathrm{P}_{2} \mathrm{O}_{5} 14 \%$, and $\mathrm{K}_{2} \mathrm{O} 14 \%$, applied as a basal fertilizer before the seedlings were transplanted. Calcium silicate slag $\left(\mathrm{SiO}_{2} \% \pm 30 \%\right)$, which is the most widely used silica ( $\mathrm{Si}$ ) material in Japan, was also applied at $7.5 \mathrm{~g}$ per pot as a $\mathrm{Si}$ application treatment. The application rate of calcium silicate slag is equivalent to 1.5 times the recommended standard in Japan. No calcium silicate slag was applied to the control pots. The tested soil contained $1.6 \%$ total C, $0.14 \%$ total N, $1.2 \mathrm{mg} \mathrm{kg}^{-1}$ of available As ( $1 \mathrm{M} \mathrm{HCl}$ extractable form), and $44.2 \mathrm{mg} \mathrm{kg}^{-1}$ of available $\mathrm{SiO}_{2}$. This soil had a $\mathrm{pH}$ of 5.5. This soil tested was not unpolluted with relatively low As concentration.

A popular Japanese cultivar (Oryza sativa L. cv. Koshihikari) was selected for rice cultivation. Hastening of germination was conducted in an incubator at $32{ }^{\circ} \mathrm{C}$ under dark conditions for $24 \mathrm{~h}$. Germinated seeds were sown in paper pots (comprised of $5781.5-\mathrm{cm}^{2}, 3-\mathrm{cm}$-deep blocks). Rice seedlings that were approx. 25 days old were transplanted to the Wagner pots on 31 May, 2018. In the center of each pot, three seedlings were transplanted, and flooding conditions were maintained from the transplanting to harvesting. At 48 days after the seedlings were transplanted, a compound liquid fertilizer containing $0.21 \% \mathrm{~N}$ as a form of $\left(\mathrm{NH}_{4}\right)_{2} \mathrm{SO}_{4}$ was applied to each pot with $0.5 \mathrm{~g}$ of $\mathrm{N}$. The plants were grown outdoors for 71 days before the start of the high-temperature treatment.

\subsection{High-Temperature Treatment during the Ripening Period}

Three 15-m-long TGCs (Figure 1) were used to investigate the As accumulation in rice grains under high-temperature conditions. For the high-temperature treatments, the TGCs were set up in the paddy field at Shimane University, Matsue, Japan $\left(35^{\circ} 29^{\prime} \mathrm{N}, 133^{\circ} 04^{\prime} \mathrm{E}, 4 \mathrm{~m}\right.$ asl). To detect the temperature variation, we applied four temperature regimens, in order, from the entrance of the TGC to deep inside the TGC: ambient, mildly-high, moderately-high, and super-high-temperature treatments. The boundaries of each treatment section were separated by a transparent nylon curtain with vertical slits. A high-quality fan was attached on the back end of each TGC and continuously provided a gentle airflow from the entrance to deep inside the TGC to create more warm heat. This set-up provided an effective way to understand and measure the temperature variation from each of the four sections of each TGC. The temperature in the mildly-high plot is close to the outside temperature (ambient plot) because the airflow passes first through the entrance, and the temperature gradually increases toward the far end of the TGC (Figure 2).

The daytime air temperature was set not to exceed $40^{\circ} \mathrm{C}$ by adjusting the fan's exhaust speed. The air temperatures and soil temperatures were recorded until harvesting. 


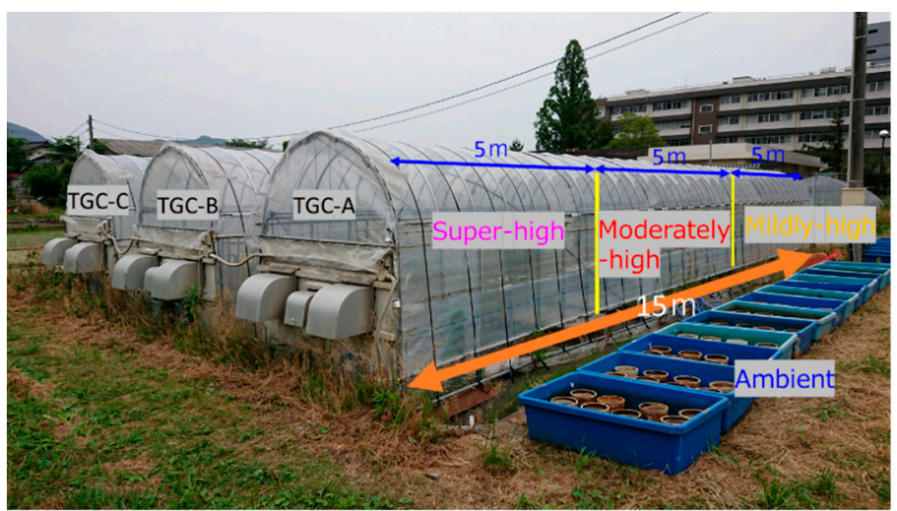

Figure 1. Three temperature gradient chambers (TGCs) used for high-temperature treatment during the ripening period.

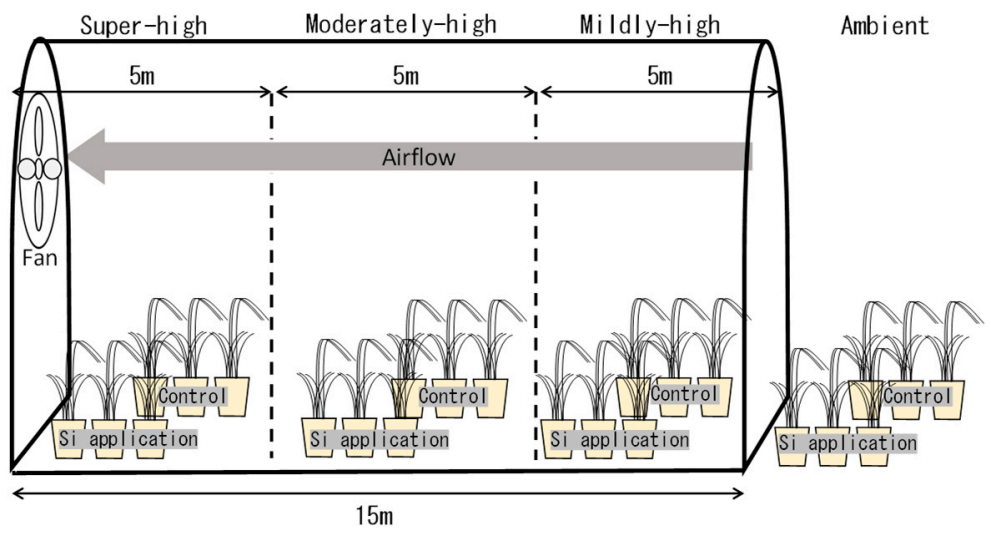

Figure 2. Schematic inside of TGC.

The heading date when $50 \%$ of the total heading occurred was 3 August. Seven days after the heading date (10 August), six pots (three control pots and three Si-application pots) were transferred to each of the four temperature treatments in each of the three TGCs. A total of 72 pots $(6 \times 4 \times 3)$ was thus used in this study. These pots were grown in the TGCs until harvesting (19 September).

\subsection{Plant Sampling}

We harvested the rice plants at maturity (19 September) from each pot for the evaluation of the As concentration in rice plant tissues. The harvested plant samples were air-dried in a greenhouse for 7 days. The air-dried samples were divided into straw and panicles. Husks and unfilled grains were removed for only the analyses of the As and speciation concentrations in brown rice grains. The panicles were divided into rachis and grains. Unfilled grains were removed by ammonium sulfate solution, and the grains were counted by a machine (IC-1, Aidex Co., Nagoya, Japan). Filled grains were de-husked by a machine (FC2K, Otake Agricultural Machinery Co., Aichi, Japan).

\subsection{Chemical Analyses of the As and Speciation in the Plant Tissues}

Five $\mathrm{mL}$ of 5:1 $(v / v) \mathrm{HNO}_{3} / \mathrm{H}_{2} \mathrm{O}_{2}$ was added to each powdered sample of brown rice $(0.5 \mathrm{~g})$, and the samples were wet-digested in a microwave oven (MLS 1200, Milestone, Bergamo, Italy). The concentrations of As in the degraded samples was determined by inductively coupled plasma mass spectrometry (ICP-MS) (ELAN DRC-e, PerkinElmer Sciex, Shelton, CT, USA).

We determined the As speciation in the rice grains by using the method of Matsumoto et al. [23]. Powdered brown rice $(0.5 \mathrm{~g})$ was mixed with $2 \mathrm{~mL}$ of $\mathrm{HNO}_{3}(0.15 \mathrm{M})$ in a 10-mL capped high-density polyethylene centrifuge tube, and the mixture was heated in an aluminum heating block at $80^{\circ} \mathrm{C}$ for 2 $\mathrm{h}$. The obtained extract was diluted to $10 \mathrm{~mL}$ with water and passed through a $0.45-\mu \mathrm{m}$ filter before 
analysis. The As speciation of diluted solution samples was determined by a high-performance liquid chromatography (HPLC)/ICP-MS system. A Super IC-Anion column (5 $\mu \mathrm{m}$ ID, $4.6 \mathrm{~mm}$ ID, $150 \mathrm{~mm}$ ID) and a guard column (Tosoh, Tokyo) equipped with an isocratic mobile phase system consisting of $10 \mathrm{mM}$ ammonium acetate and an HPLC system (PU 712i, GL Sciences, Tokyo, Japan) were used. The injection volume and mobile-phase flow were set at 10 and $800 \mu \mathrm{L} \mathrm{min}^{-1}$, respectively. Arsenic concentration was determined using the ELAN DRC-e ICP-MS system.

Total inorganic As (iAs) is expressed as the sum of arsenite and arsenate. The accuracy of the analysis was certified by the reference material (CRM) (rice flour, NMIJ CRM 7503-a: arsenite $0.0711 \pm 0.0029 \mathrm{mg} \mathrm{kg}^{-1}$, arsenite $0.0130 \pm 0.0009 \mathrm{mg} \mathrm{kg}^{-1}$, dimethyl arsenate (DMA) $0.0133 \pm 0.0009 \mathrm{mg} \mathrm{kg}^{-1}$; National Institute of Advanced Industrial Science and Technology (NIJM), Tsukuba, Japan).

\subsection{Statistical Analyses}

The representative values of growth and As concentration in each temperature treatment in each TGC were taken as the average of three pots. The effects of temperature on the growth and As concentrations in brown rice were validated by an analysis of covariance (ANCOVA) with air or soil temperature as a covariate. We also tested the significance of the control and $\mathrm{Si}$ application when the ANCOVA was significant.

\section{Results}

3.1. Temperature Differences between the Ambient, Mildly-High, Moderately-High, and Super-High Treatments in the TGCs during the Ripening Period

The daily air temperature differences among the four temperature treatments for the $T_{\text {mean }}, T_{\max }$, and $\mathrm{T}_{\min }$ in the TGCs during the ripening period are shown in Figure 3. According to the daily temperature data, the differences in the average daily air temperatures among the four treatments (i.e., ambient, mildly-high, moderately-high, and super-high temperatures) were $1.1^{\circ} \mathrm{C}-2.0^{\circ} \mathrm{C}\left(\mathrm{T}_{\text {mean }}\right)$, $3.6^{\circ} \mathrm{C}-4.0^{\circ} \mathrm{C}\left(\mathrm{T}_{\max }\right)$, and $0.10^{\circ} \mathrm{C}-0.9^{\circ} \mathrm{C}\left(\mathrm{T}_{\min }\right)$, respectively. As summarized in Table 1 , the average daily mean air temperature during the ripening period was $25.9^{\circ} \mathrm{C}$ in the ambient sections of the TGCs, $27.0^{\circ} \mathrm{C}$ in the mildly-high sections, $27.9^{\circ} \mathrm{C}$ in the moderately-high sections, and $27.8^{\circ} \mathrm{C}$ in the super-high temperature sections. Therefore, the greatest difference between the average daily mean temperatures observed in the daily temperature data during the ripening period was $2.0^{\circ} \mathrm{C}$.

The average daily maximum air temperature was $30.6^{\circ} \mathrm{C}$ in the ambient-temperature sections, $33.6{ }^{\circ} \mathrm{C}$ in the mildly-high, $34.6^{\circ} \mathrm{C}$ in the moderately-high, and $34.5^{\circ} \mathrm{C}$ in the super-high; as a result, the difference in the average daily maximum air temperatures among the four temperature treatments during the ripening period was $3.0^{\circ} \mathrm{C}$.

In contrast, the data in Table 1 show that the average daily air minimum temperature was $22.7^{\circ} \mathrm{C}$ in the ambient, $22.6^{\circ} \mathrm{C}$ in the mildly-high, $23.7^{\circ} \mathrm{C}$ in the moderately-high, and $23.6^{\circ} \mathrm{C}$ in the super-high sections during the ripening period. From the daily minimum temperature data, the difference in the average daily air minimum temperature during the ripening period was $1.1^{\circ} \mathrm{C}$. Based on the daily minimum temperature data, there were clear temperature differences between the four high-temperature treatments. We thus observed an effective and meaningful air temperature difference between the ambient-temperature sections of the TGCs and the three high-temperature treatments.

The daily soil temperature differences are shown in Figure 4 for the four temperature sections in the TGCs for the $\mathrm{T}_{\text {mean }}, \mathrm{T}_{\max }$, and $\mathrm{T}_{\min }$. The variations in the daily soil temperature differences among the ambient, mildly-high, moderately-high, and super-high treatments were $0.2^{\circ} \mathrm{C}-3.3^{\circ} \mathrm{C}\left(\mathrm{T}_{\text {mean }}\right)$, $0.5^{\circ} \mathrm{C}-2.6{ }^{\circ} \mathrm{C}\left(\mathrm{T}_{\max }\right)$, and $0.5^{\circ} \mathrm{C}-1.7^{\circ} \mathrm{C}\left(\mathrm{T}_{\min }\right)$. The average daily soil temperature differences for $\mathrm{T}_{\text {mean }}$ and $\mathrm{T}_{\max }$ between the ambient and high-temperature treatments differed slightly among the three TGCs. Generally, the range of temperature differences for $\mathrm{T}_{\min }$ was smaller than that for $\mathrm{T}_{\max }$ during the ripening period. 

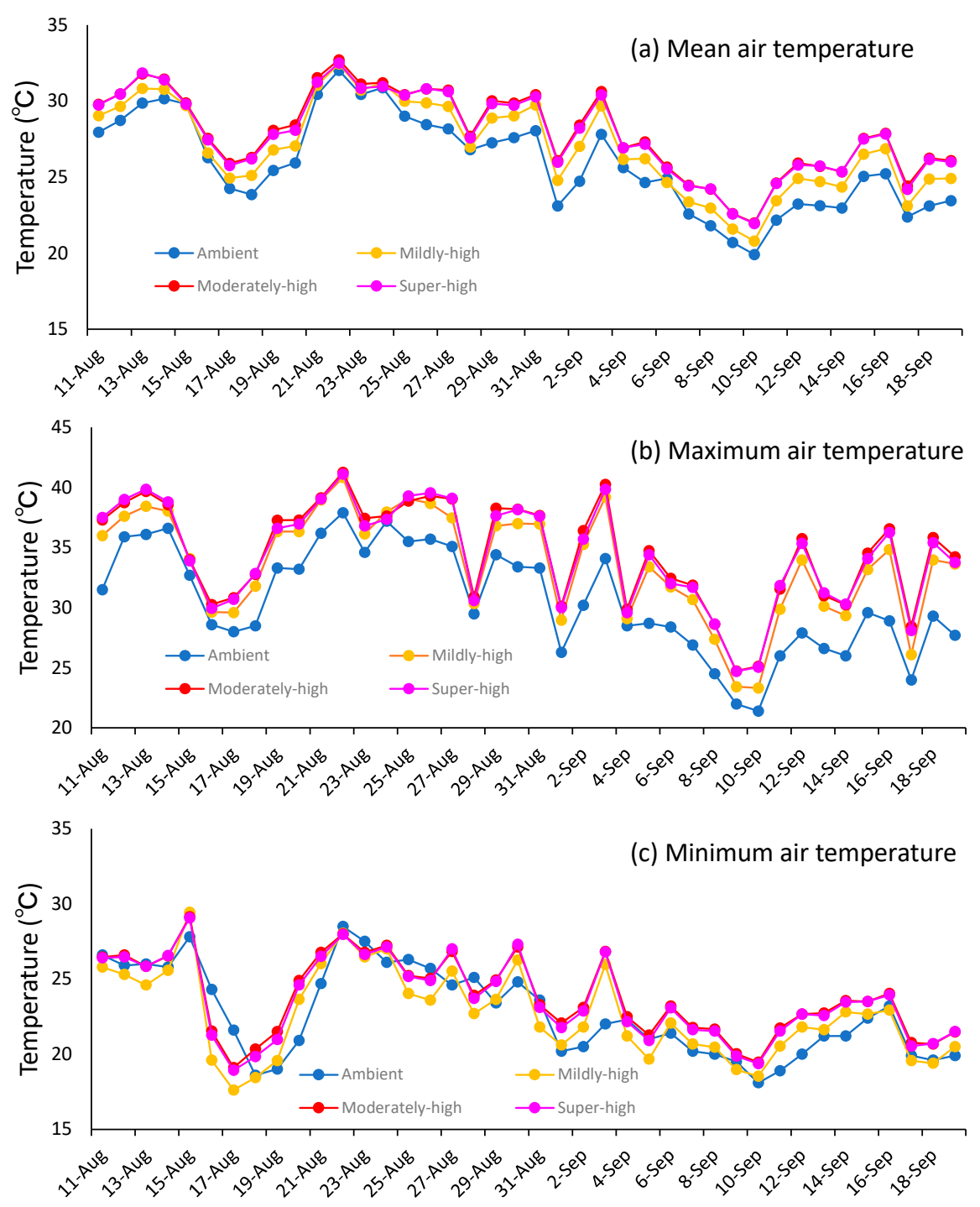

Figure 3. Changes in average daily mean air temperature (a), daily maximum air temperature (b), and daily minimum air temperature (c) during the ripening period.

Table 1. Average air and soil temperature during ripening period.

\begin{tabular}{ccccccc}
\hline \multirow{2}{*}{ Temperature } & \multicolumn{3}{c}{ Air Temperature $\left({ }^{\circ} \mathbf{C}\right)$} & \multicolumn{3}{c}{ Soil Temperature $\left({ }^{\circ} \mathbf{C}\right)$} \\
\cline { 2 - 7 } & Mean & Maximum & Minimum & Mean & Maximum & Minimum \\
\hline Ambient & 25.9 & 30.6 & 22.7 & 25.7 & 27.9 & 24.3 \\
Mildly-high & 27.0 & 33.6 & 22.6 & 26.9 & 29.5 & 24.9 \\
Moderately-high & 27.9 & 34.6 & 23.7 & 27.5 & 30.0 & 25.5 \\
Super-high & 27.8 & 34.5 & 23.6 & 28.0 & 30.5 & 26.0 \\
\hline
\end{tabular}

The average daily mean soil temperature during the ripening period was $25.7^{\circ} \mathrm{C}$ in the ambient, $26.9{ }^{\circ} \mathrm{C}$ in the mildly-high, $27.5^{\circ} \mathrm{C}$ in the moderately-high, and $28.0^{\circ} \mathrm{C}$ in the super-high sections (Table 1); thus the difference in the soil average daily mean temperatures among the four treatments was high, at $2.3^{\circ} \mathrm{C}$. However, our evaluation showed that the average daily soil maximum temperature during the ripening period was $27.9^{\circ} \mathrm{C}$ in the ambient, $29.5{ }^{\circ} \mathrm{C}$ in the mildly-high, $30.0{ }^{\circ} \mathrm{C}$ in the moderately-high, and $30.5^{\circ} \mathrm{C}$ in the super-high sections of the TGCs. We had expected that the daily soil maximum temperature difference would be high. The average daily soil minimum temperature during the ripening period was $24.3^{\circ} \mathrm{C}$ in the ambient, $24.9{ }^{\circ} \mathrm{C}$ in the mildly-high, $25.5{ }^{\circ} \mathrm{C}$ in the 
moderately-high, and $26.0^{\circ} \mathrm{C}$ in the super-high sections. The difference in the average daily minimum temperatures during the ripening period was thus $1.7^{\circ} \mathrm{C}$. Based on these soil temperatures data, we detected an effective soil temperature difference among the temperature treatments.
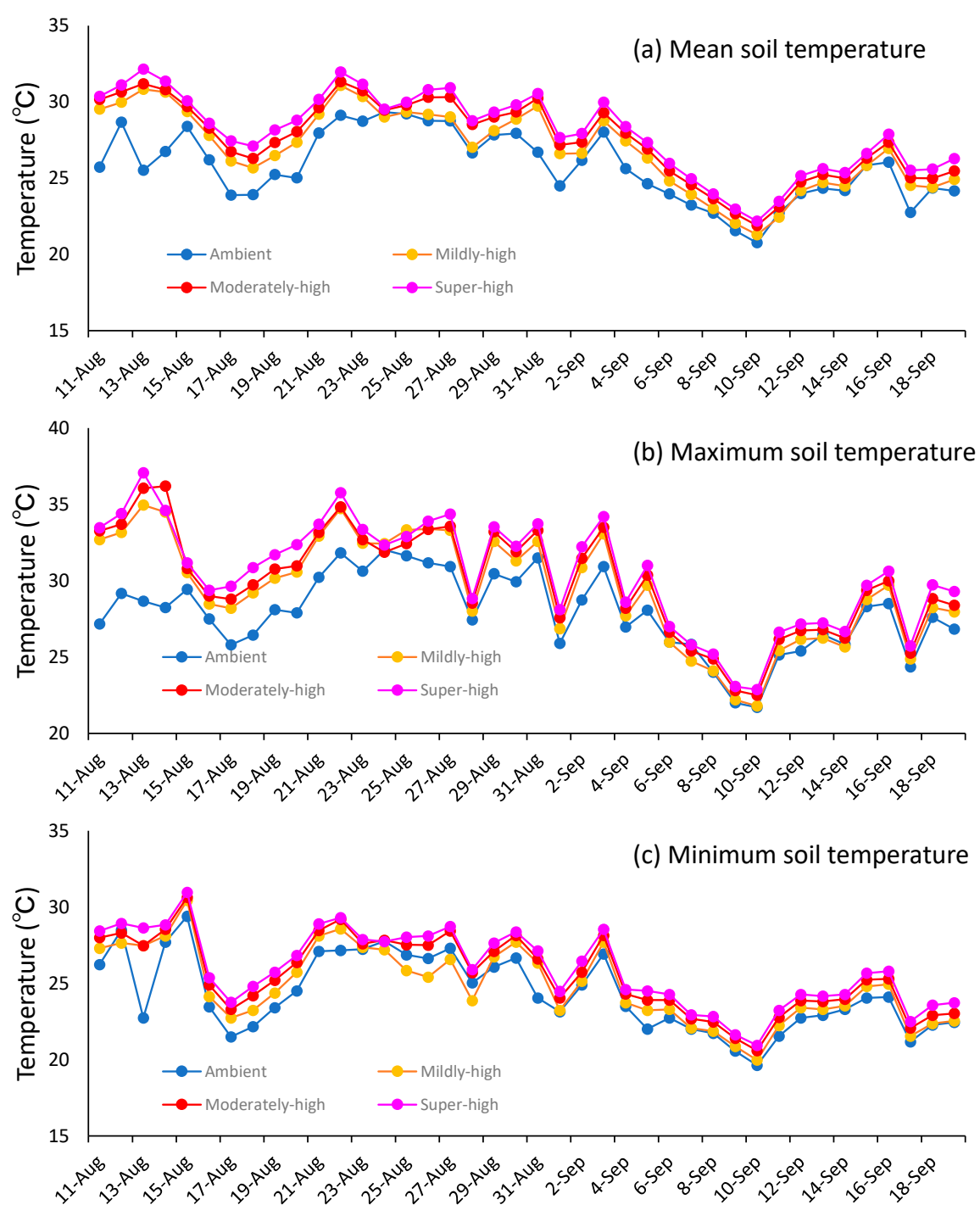

Figure 4. Changes in average daily mean soil temperature (a), daily maximum soil temperature (b), and daily minimum soil temperature (c) during the ripening period.

3.2. Effects of Temperature during Ripening Period and Si Application on the Biomass Production and Brown Rice Yield

The data of the dry matter production (straw and panicle) and brown rice yield are shown in Supplementary Table S1. These data were analyzed by ANCOVA with the average air or soil temperature after heading as a covariate and $\mathrm{Si}$ application as a fixed factor (Table 2). No significance of regression was observed for the straw weight. We thus consider that the straw weight was not affected by the increases in the air and soil temperatures after heading. In contrast, the significance of regression was recognized for the panicle weight and brown rice yield; that is, it was confirmed that the panicle weight and brown rice yield decreased significantly as the air and soil temperatures increased during the ripening period. The ANCOVA revealed a significant effect of the Si application. The Si application significantly increased the dry matter production (straw and panicle) and the brown rice yield in all of the temperature ranges. Thus, the application of silicate effectively increased the dry matter production and brown rice yield even in high-temperature conditions during the ripening period. 
Table 2. Effect of the temperature and Si application on the dry matter production and brown rice yield.

\begin{tabular}{|c|c|c|c|c|c|c|c|c|c|c|}
\hline \multirow[b]{2}{*}{ Main Factor } & \multirow[b]{2}{*}{ Treatment } & \multicolumn{6}{|c|}{ Dry Matter Production } & \multirow{2}{*}{\multicolumn{3}{|c|}{$\begin{array}{c}\text { Brown Rice Yield } \\
\qquad\left(\mathrm{g} \mathrm{pot}^{-1}\right)\end{array}$}} \\
\hline & & \multicolumn{3}{|c|}{$\begin{array}{c}\text { Straw } \\
\left(\mathrm{g} \mathrm{pot}^{-1}\right)\end{array}$} & \multicolumn{3}{|c|}{$\begin{array}{c}\text { Panicle } \\
\left(\mathrm{g} \mathrm{pot}^{-1}\right)\end{array}$} & & & \\
\hline \multirow{4}{*}{ Temperature } & Ambient & 18.5 & \pm & 1.2 & 22.9 & \pm & 1.2 & 18.5 & \pm & 1.0 \\
\hline & Mildly-high & 18.7 & \pm & 1.6 & 16.7 & \pm & 1.3 & 12.4 & \pm & 0.9 \\
\hline & Moderately-high & 20.4 & \pm & 2.6 & 15.6 & \pm & 2.0 & 11.3 & \pm & 1.5 \\
\hline & Super-high & 20.2 & \pm & 2.3 & 16.4 & \pm & 2.3 & 11.9 & \pm & 1.7 \\
\hline \multirow{2}{*}{ Si application } & Control & 15.8 & \pm & 0.6 & 14.7 & \pm & 1.1 & 11.2 & \pm & 1.0 \\
\hline & Calcium silicate slug & 23.1 & \pm & 1.0 & 21.1 & \pm & 1.1 & 15.9 & \pm & 1.0 \\
\hline \multirow{3}{*}{$\begin{array}{l}\text { ANCOVA } \\
\text { Significance of } \\
\text { regression }\end{array}$} & & & & & & & & & & \\
\hline & Mean air temperature & $p$ & $=$ & 0.125 & $p$ & $<$ & 0.001 & $p$ & $<$ & 0.001 \\
\hline & Mean soil temperature & $p$ & $=$ & 0.192 & $p$ & $<$ & 0.001 & $p$ & $<$ & 0.001 \\
\hline \multirow{2}{*}{ Si application } & Mean air temperature & $p$ & $<$ & 0.001 & $p$ & $<$ & 0.001 & $p$ & $<$ & 0.001 \\
\hline & Mean soil temperature & $p$ & $<$ & 0.001 & $p$ & $<$ & 0.001 & $p$ & $<$ & 0.001 \\
\hline
\end{tabular}

3.3. Effects of Temperature during the Ripening Period and the Si Application on the As Concentration and As Speciation in Brown Rice

The results of our analyses of As in brown rice are summarized in Supplementary Table S2, and the relationships between the As concentration and the temperature and Si application are illustrated in Figure 5. The proportions of the concentration of the sum of As species to that of total As in the brown rice ranged from $90 \%$ to $97 \%$ (mean: $94 \%$ ), indicating that the accuracy of the speciation analysis was reasonable (Table S2). The average proportion of the concentration of iAs to total As was $73.7 \%$, and as reported [23], iAs was the dominant form of As present in the brown rice, and the degree of the changes with temperature treatment and Si application was small. The average proportion of DMA to total As was approx. 20\%, and the variation between treatments was small.

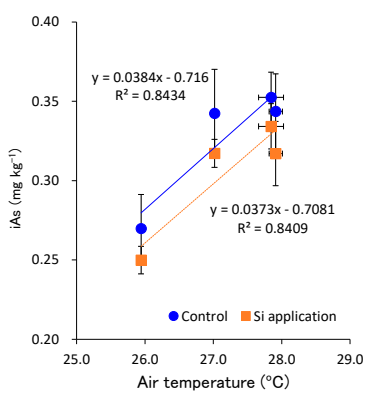

(a) Inorganic As
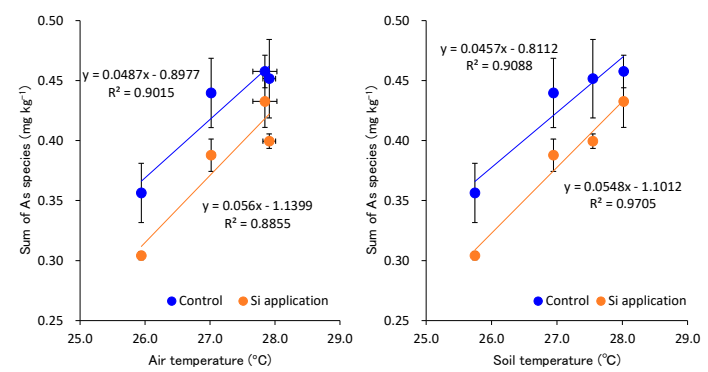

(c) Sum of As species
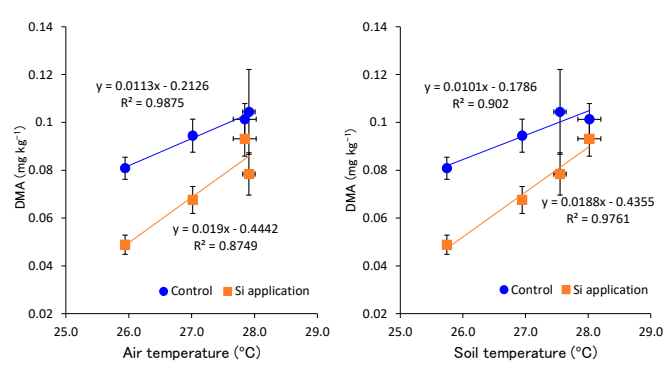

(b) DMA
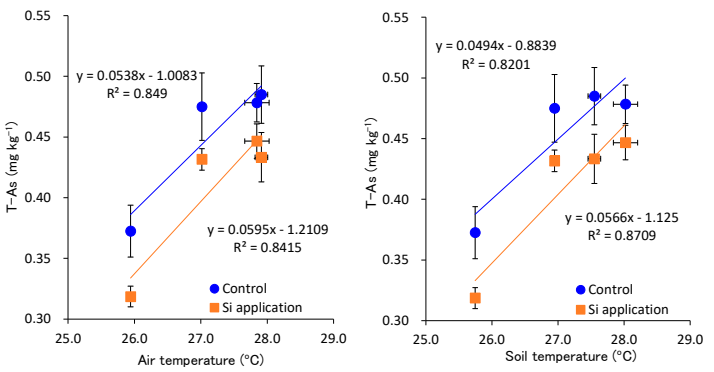

(d) Total As

Figure 5. Relationships between air and soil temperature during the ripening period and the concentrations of arsenic species in brown rice. 
The concentrations of iAs and DMA increased significantly with the increasing air and soil temperatures during the ripening period in both the control and Si application (Figure 5). The monomethyl arsonate (MMA) concentration was extremely low in all treatments, and its relationships with the air and soil temperatures were not clear. As mentioned above, since the dominant forms of As in brown rice were iAs and DMA, similarly, the concentration of total As and the sum of As species also increased significantly with the increasing temperatures. The concentration of As (except MMA) in the brown rice tended to be lower in the Si application than in the control in any temperature range. Therefore, for the As species that showed a linear relationship with these temperatures, we performed an ANCOVA using the soil temperature and air temperature as covariates, and we analyzed the As reduction effect of the Si application under elevated temperature.

The results of the ANCOVA revealed significant linear relationships between the concentrations of iAs, DMA, the sum of As species, and total As with the average air and soil temperatures during the ripening period (Table 3). The effect of the Si application on the concentration of iAs was nonsignificant when the significance level of $5 \%$ was used but was significantly reduced at the significance level of $10 \%$. The concentrations of DMA, the sum of As species, and the total As were significantly reduced by the $\mathrm{Si}$ application at a significance level of $<0.1 \%$. These results confirmed that the increase in air and soil temperatures during the ripening period significantly increased the As concentration in brown rice, but the $\mathrm{Si}$ application was effective in reducing the As concentration in brown rice compared to the control at all of the temperatures used herein.

Table 3. Effects of the temperature treatment during the ripening period and Si application on the arsenic (As) concentrations in brown rice.

\begin{tabular}{|c|c|c|c|c|c|c|c|c|c|c|c|c|c|c|c|c|}
\hline \multirow{3}{*}{$\begin{array}{l}\text { Main Factor } \\
\text { Temperature }\end{array}$} & \multirow{3}{*}{$\begin{array}{l}\text { Treatment } \\
\text { Ambient }\end{array}$} & \multirow{2}{*}{\multicolumn{3}{|c|}{$\begin{array}{c}\text { Inorganic As } \\
\left(\mathrm{mg} \mathrm{kg}^{-1}\right)\end{array}$}} & \multirow{2}{*}{\multicolumn{3}{|c|}{$\begin{array}{c}\text { DMA } \\
\left(\mathrm{mg} \mathrm{kg}^{-1}\right)\end{array}$}} & \multirow{2}{*}{\multicolumn{3}{|c|}{$\begin{array}{c}\text { MMA } \\
\left(\mathrm{mg} \mathrm{kg}^{-1}\right)\end{array}$}} & \multirow{2}{*}{\multicolumn{3}{|c|}{$\begin{array}{l}\text { Sum of As } \\
\text { Species } \\
\left(\mathrm{mg} \mathrm{kg}^{-1}\right)\end{array}$}} & \multirow{2}{*}{\multicolumn{3}{|c|}{$\begin{array}{l}\text { Total As } \\
\left(\mathrm{mg} \mathrm{kg}^{-1}\right)\end{array}$}} \\
\hline & & & & & & & & & & & & & & & & \\
\hline & & 0.260 & \pm & 0.011 & 0.065 & \pm & 0.008 & 0.005 & \pm & 0.000 & 0.330 & \pm & 0.016 & 0.346 & \pm & 0.016 \\
\hline \multirow{3}{*}{ (2) } & Mildly-high & 0.330 & \pm & 0.014 & 0.081 & \pm & 0.007 & 0.003 & \pm & 0.000 & 0.414 & \pm & 0.018 & 0.453 & \pm & 0.016 \\
\hline & Moderately-high & 0.330 & \pm & 0.009 & 0.091 & \pm & 0.011 & 0.004 & \pm & 0.000 & 0.425 & \pm & 0.019 & 0.459 & \pm & 0.018 \\
\hline & Super-high & 0.343 & \pm & 0.011 & 0.097 & \pm & 0.005 & 0.004 & \pm & 0.001 & 0.445 & \pm & 0.013 & 0.463 & \pm & 0.012 \\
\hline Si application & Calcium silicate slug & 0.305 & \pm & 0.011 & 0.072 & \pm & 0.006 & 0.004 & \pm & 0.000 & 0.381 & \pm & 0.015 & 0.408 & \pm & 0.017 \\
\hline \multicolumn{17}{|l|}{ Ancova } \\
\hline \multirow{2}{*}{$\begin{array}{l}\text { Significance of } \\
\text { regression }\end{array}$} & Mean air temperature & $p$ & $<$ & 0.001 & $p$ & $<$ & 0.001 & $p$ & $=$ & 0.071 & $p$ & $<$ & 0.001 & $p$ & $<$ & 0.001 \\
\hline & Mean soil temperature & $p$ & $<$ & 0.001 & $p$ & $<$ & 0.001 & $p$ & $=$ & 0.150 & $p$ & $<$ & 0.001 & $p$ & $<$ & 0.001 \\
\hline Si application & Mean air temperature & $p$ & $=$ & 0.067 & $p$ & $<$ & 0.001 & $p$ & $=$ & 0.458 & $p$ & $=$ & 0.005 & $p$ & $=$ & 0.008 \\
\hline
\end{tabular}

\section{Discussion}

The significant effects of high global temperature on global food production are a severe problem that needs urgent action. As many researchers predicted, increased temperatures can reduce the rice production yield. Tao et al. [24] used the 30-year period of 1961-1990 climatic data in their efforts toward the development of effective techniques to combat the effects of global warming on rice production. They reported that at $1{ }^{\circ} \mathrm{C}, 2{ }^{\circ} \mathrm{C}$, and $3{ }^{\circ} \mathrm{C}$ increases in the mean temperature, the decreases in the rice yield were $6.1 \%-18.6 \%, 13.5 \%-31.9 \%$, and $23.6 \%-40.2 \%$, respectively [24]. In our present investigation, the average temperature observed during the ripening period in the three high-temperature treatments in the TGCs was up to $2{ }^{\circ} \mathrm{C}$ higher than the ambient treatment's temperature $\left(25.9^{\circ} \mathrm{C}\right)$. Similarly, a range of $2.3^{\circ} \mathrm{C}$ higher mean soil temperature was observed compared to $25.7^{\circ} \mathrm{C}$ for the ambient treatment. In this situation, a significant negative regression equation was obtained for the brown rice yield with increasing air and soil temperatures, and the brown rice yields in the moderately-high temperature treatment and super-high temperature treatment were approx. 39\% lower than the ambient treatment.

The rate of photosynthesis decreases when the temperature increases above the optimum value for plant growth [25], and it has thus been shown that a reduced ripening period leads to an inadequate 
accumulation of carbohydrates and to a decrease in yield due to increases in sterility and immature grains [26-30]. In the present study, the yields were significantly higher in the Si application compared to the control. Even in the Si application, the yield was significantly reduced by high temperature, but the yield reduction was lessened compared to the control. In other words, our results demonstrated that $\mathrm{Si}$ application would be an effective agronomic management technique to minimize yield losses under high-temperature conditions.

Agostinho et al. [29] suggested that the application of different Si sources increased not only the biomass $\mathrm{Si}$ content but also the Si content at the tillering, booting, and flowering stages by $12 \%$, $10 \%$, and $23 \%$ respectively, and that the increase in Si content increased grain yield by $4.46 \%-5.38 \%$. In an investigation by Mato et al. [30], that the photosynthetic rate of single leaves was improved by increasing the concentration of $\mathrm{Si}$ in the leaf blade by the application of calcium silicate, and those authors noted that this improvement occurred because the leaf blade maintains the plant's functional water status. Ando et al. [31] showed that the photosynthetic rate of the community of rice was increased by the application of calcium silicate, and the carbohydrate content in the rice grains was also increased. A later study by Fujii et al. [32] revealed that paddy rice leaves rich in $\mathrm{Si}$ had an increase in carbohydrate content and a good ripening performance through an increase in photosynthetic rates to maintain the functional water status.

In 2010, Kaneda et al. [33] demonstrated in a pot experiment that a rapid increase in leaf temperature in response to high-temperature treatment was suppressed by an application of calcium silicate from the ripening stage, and this application was also speculated to suppress the decrease in yield and improve the quality of brown rice by suppressing the consumption of carbohydrates accumulated in the leaf blade. In fact, Mori and Fujii [34] reported that the fructose, glucose, and sucrose content in the leaves after high-temperature treatment was 1.4 times higher with the application of calcium silicate compared to the control, suggesting that this change in content was a factor in reducing the decline in yield and quality. As mentioned above, we propose that the application of $\mathrm{Si}$ could be a promising soil fertilizer to control the degradation of yield and quality under high-temperature conditions.

The impact of high temperatures on the As concentration from a soil solution to the rice grain has recently been examined with high air temperatures after heading and elevated soil temperature [35]. Weber et al. [36] reported the relationship between the increase or decrease in soil temperature and the leaching of arsenic into the soil solution as follows. When the soil temperature increased from $10{ }^{\circ} \mathrm{C}$ to $>23^{\circ} \mathrm{C}$, As was rapidly released into the soil solution with an increase in microbial activity. In contrast, when the soil temperature was decreased from $23^{\circ} \mathrm{C}$ to $14{ }^{\circ} \mathrm{C}$ or $5^{\circ} \mathrm{C}$, the As concentration was 10 times lower at $14{ }^{\circ} \mathrm{C}$ or $5^{\circ} \mathrm{C}$ compared to that at $23^{\circ} \mathrm{C}$ [36]. Tyrovola et al. [37] reported that the As concentration in soil solution kept at $40^{\circ} \mathrm{C}$ was higher than those at $10^{\circ} \mathrm{C}$ and $20^{\circ} \mathrm{C}$. Neumann et al. [35] cultivated rice plants in California paddy soil packed into rhizome boxes, using different soil temperatures $\left(26.1^{\circ} \mathrm{C}\right.$ and $\left.30.5^{\circ} \mathrm{C}\right)$, and synchrotron X-ray fluorescence (XRF) imaging at the root base of the rice plants showed that more iron (Fe and As were accumulated at $30.5^{\circ} \mathrm{C}$ compared to $26.1^{\circ} \mathrm{C}$ soil-temperature treatment). Regarding these results, Neumann et al. suggested that the increased soil temperature increased the activity of the iron-reducing bacteria and that the leaching of iron from the solid phase into the soil solution increased the leaching of As that was adsorbed by the iron in the soil.

Arao et al. [5] recently reported multiyear data revealing that the daily mean high temperature during the 2-4 weeks post-heading was significantly correlated with the iAs concentrations in the rice grains, indicating that this period ( $2-4$ weeks post-heading) is important in the uptake and accumulation of As in rice grains. Together the above-summarized studies demonstrated that high air and soil temperatures are the most important factors needed to release more As in the soil solution, and that these increased temperatures are related to the transfer of As from the rice root to grains and deposited more As in rice grains compared to the optimum temperature.

We observed herein that the average mean soil temperature was $25.7^{\circ} \mathrm{C}$ in the ambient treatment in the TGCs, $26.9^{\circ} \mathrm{C}$ in the mildly-high treatment, $27.5^{\circ} \mathrm{C}$ in the moderately-high treatment, and $28.0^{\circ} \mathrm{C}$ in the super-high temperature treatment (Table 1). Although we did not measure the concentration of 
As in the soil solution during the growing period, the concentration of As in the soil solution likely remained higher in the high-temperature treatments, as is evident from many of the above reports. Our experiment showed that the As concentrations of brown rice in the high-temperature treatments remained higher than that in the ambient treatment. In fact, with the use of the TGCs, the concentration of As in brown rice showed a significant positive correlation with the air and soil temperatures during the ripening period and was higher as the air and ground temperatures increased. Our findings thus support the relationship between air temperature during the ripening period and the brown rice As concentration suggested by Arao et al. [5].

We also observed that the $\mathrm{Si}$ application had a significant effect on the As accumulation in brown rice grains (Table 3). Many researchers have reported that the application of Si materials is more beneficial and effective to reduce the As uptake and concentration in rice grains. Matsumoto et al. [19] cultivated rice plants in concrete frames in a field and applied calcium silicate treatment; they reported that this treatment effectively reduced the As concentration in the grain and straw compared to the control (without calcium silicate application). Bogdan and Schenk [38] showed that soils containing high levels of $\mathrm{Si}$ that is available to plants produce lower concentrations of As in rice plants and that the application of $\mathrm{Si}$ to the soil may reduce the concentration of As in rice. Moreover, Li et al. [39] observed that the application of Si fertilizer to the soil reduced the total As of rice straw and grain by $78 \%$ and $16 \%$, respectively. Even different sources of Si materials (i.e., Si-potash fertilizer, Si-Ca fertilizer, semi-finished product of Si-potash fertilizer, and $\mathrm{Na}_{2} \mathrm{Sio}_{3}$ ) showed reduced As concentrations in both straw and grain [40].

It has been reported that the similarity between the chemical forms of As and $\mathrm{Si}$ is an essential factor in considering the decrease in the As concentration of brown rice due to silicate application. Several research groups noted that the addition of Si significantly elevated the As concentration in soil solution, and that it even decreased the accumulation of As in some important aerial parts of the plant (stem, leaf, husk, and grain). Arsenic and Si are competitive elements for ferrihydrite and gothite [41-43] because of their chemical similarities. The increase in As concentration in the soil solution caused by the addition of $\mathrm{Si}$ is the result of competitive adsorption between silicate and arsenite on soil particles that are rich in iron oxide [39]. The competitive adsorption to the binding sites also occurred in the iron plaque of rice roots [39]. Thus, the competition between As and Si at the root surface should not increase the absorption of As by rice, even if the concentration of As in the soil solution increases [44].

It has been pointed out that the competition between As and Si has a significant influence on the process of As uptake by rice. Ma et al. concluded that arsenite (which is the dominant species of iAs in rice) and Si are transported by the same transporters (i.e., Lsi1 and Lsi2) because of the chemical similarities between arsenite and Si [45]. In the present study, the application of calcium silicate had a considerable effect on the concentration of As in brown rice grains, as shown in Table 3 . The concentrations of the dominant As species (iAs and DMA) in brown rice were significantly decreased by the $\mathrm{Si}$ application compared to the control without $\mathrm{Si}$ application at all temperatures tested. Similar results were observed by Li et al. [39], who also documented in their pot experiment using rice plants grown at the temperature range $22{ }^{\circ} \mathrm{C}-35^{\circ} \mathrm{C}$ that an application of Si significantly reduced the total As concentration in brown rice grains (by $24.1 \%$ ), whereas the Si had only a slight and non-significant effect on the plant biomass [39]. The decrease in As concentration could be due to the competition of $\mathrm{Si}$ in the arsenite uptake and transport in aerial tissues.

Several studies showed that Si may suppress the arsenite uptake in a direct competition for membrane transporters, especially Lsi2 [45-47]. An increase in the Si concentration in the rice body by the application of silicate can thus affect and compete with As for the transportation, and therefore mitigate the As absorption in rice, which is related to decreasing As contents in rice straw, followed by a decreased As concentration in rice grains under the high-temperature conditions described herein. These findings indicate that the competitive As uptake reduction by the application of silicate was effective even under high-temperature conditions. In addition, the increase in biomass and brown rice 
yield by the application of calcium silicate may have contributed to the decrease of the concentration of As in brown rice. In other words, if the accumulation of carbohydrates in brown rice is increased, the concentration of As in brown rice is considered to be diluted and decreased. In this regard, it is necessary to examine the relationship between the accumulation of carbohydrates and As in brown rice because it has been clarified that iAs translocates to brown rice through a sieve tube as described above $[16,17]$. The cause of the decrease in brown rice yield due to high temperature is that the high temperature accelerates the aging of the leaf and panicle, and the ripening period is shortened [48]. Therefore, the reason for the high concentration of As in brown rice in high-temperature conditions may be that the dilution of As due to the accumulation of carbohydrates was insufficient for the shortened ripening period. The reason the concentration of As in the Si treatment was lower than that in the control may also be that the ripening damage due to high temperature was less than that in the control. However, such considerations would require a detailed study of the translocation rates of carbohydrates and As to brown rice, respectively. The application of Si would thus reduce the risk of human As intake from rice cultivated under high temperature.

It is important to note that the amount of calcium silicate applied in this study was approx. 1.5 times the recommended standard in Japan. This was because the available Si content of the soil used in this study was lower than that of the average paddy field soil in Japan. In addition, to assess the risk of As in rice sold at public markets, we tested soil with relatively low As concentrations. These factors may have facilitated the effect of the $\mathrm{Si}$ application on the mitigation of growth inhibition and reduction of As concentration in brown rice under high-temperature conditions. It is therefore necessary to study the amounts of $\mathrm{Si}$ applied according to the As and available $\mathrm{Si}$ contents in the soil. Further investigations of agronomic methods are required in a variety of field conditions to determine all of the precise effects of increased temperatures.

Supplementary Materials: The following are available online at http://www.mdpi.com/2077-0472/10/7/289/s1, Table S1: Dry matter production and brown rice yield in the present study, Table S2: Concentrations of As species in brown rice in the present study.

Author Contributions: Conceptualization, A.T. and S.M.; methodology, K.K.; validation, K.U., F.A. and J.K.; formal analysis, I.A. and J.K.; investigation, P.D., J.K., and S.M.; data curation, T.A.; writing-original draft preparation, P.D.; writing - review and editing, S.M. and K.K.; supervision, T.A.; project administration, S.M.; funding acquisition, T.A. and S.M. All authors have read and agreed to the published version of the manuscript.

Funding: This research was partially supported by the National Science Foundation grant No. 18065121.

Conflicts of Interest: The authors declare no conflicts of interest in this research study.

\section{References}

1. IPCC. Climate Change 2014: Synthesis Report. Contribution of Working Groups I, II and III to the Fifth Assessment Report of the Intergovernmental Panel on Climate Change; Core Writing Team, Pachauri, R.K., Meyer, L.A., Eds.; IPCC: Geneva, Switzerland, 2014; Available online: https://www.ipcc.ch/site/assets/uploads/2018/02/SYR_ AR5_FINAL_full.pdf (accessed on 6 April 2020).

2. Morita, S. Prospect for developing measures to prevent high-temperature damage to rice grain ripening. Jpn. J. Crop Sci. 2008, 77, 1-12. [CrossRef]

3. Peng, S.; Huang, J.; Sheehy, J.E.; Laza, R.C.; Visperas, R.M.; Zhong, X.; Centeno, G.S.; Khush, G.S.; Cassman, K.G. Rice yields decline with higher night temperature from global warming. Proc. Natl. Acad. Sci. USA 2004, 101, 9971-9975. [CrossRef] [PubMed]

4. Morita, S.; Nakano, H. Nonstructural carbohydrate content in the stem at full heading contributes to high performance of ripening in heat-tolerant rice cultivar Nikomaru. Crop Sci. 2011, 51, 818-828. [CrossRef]

5. Arao, T.; Makino, T.; Kawasaki, A.; Akahane, I.; Kiho, N. Effect of air temperature after heading of rice on the arsenic concentration of grain. Soil Sci. Plant Nutr. 2018, 64, 433-437. [CrossRef]

6. Codex Alimentarius Commission 2016. In Proceedings of the Rep16/cf Joint FAO/WHO Food Standards Programme Codex Alimentarius Commission 39th Session, Rome, Italy, 27 June-1 July 2016; p. 37.

7. Kabata-Pendias, A. Trace Elements in Soils and Plants, 3rd ed.; CRC Press Inc.: Boca Raton, FL, USA, 2000; pp. 225-230. 
8. Ma, L.Q.; Komar, K.M.; Tu, C.; Zhang, W.; Cai, Y.; Kennelley, E. A fern that hyperaccumulates arsenic. Nature 2001, 409, 579. [CrossRef] [PubMed]

9. Allaway, W.H. Agronomic controls over the environmental cycling of trace elements. Advan. Agron. 1968, 20, 235-274.

10. Feng, X.; Han, L.; Chao, D.; Liu, D.; Zhang, Y.; Wang, R.; Guo, J.; Feng, R.; Xu, Y.; Ding, Y.; et al. Ionomic and transcriptomic analysis provides new insight into the distribution and transport of cadmium and arsenic in rice. J. Hazard. Mater. 2017, 331, 246-256. [CrossRef] [PubMed]

11. Takahashi, Y.; Minamikawa, R.; Hattori, K.H.; Kurishima, K.; Kihou, N.; Yuita, K. Arsenic behavior in paddy fields during the cycle of flooded and non-flooded periods. Environ. Sci. Technol. 2004, 38, 1038-1044. [CrossRef]

12. Zavala, Y.J.; Gerads, R.; Gurleyuk, H.; Duxbury, J.M. Arsenic in rice: II. Arsenic speciation in USA grain and implications for human health. Environ. Sci. Technol. 2008, 42, 3861-3866. [CrossRef]

13. Meharg, A.A.; Williams, P.N.; Adomako, E.; Lawgali, Y.Y.; Deacon, C.; Villada, A.; Cambell, R.C.J.; Sun, G.; Zhu, Y.G.; Feldmann, J.; et al. Geographical variation in total and inorganic arsenic content of polished (white) rice. Environ. Sci. Technol. 2009, 43, 1612-1617. [CrossRef]

14. Ashraf, M.A.; Umetsu, K.; Ponomarenko, O.; Saito, M.; Aslam, M.; Antipova, O.; Dolgova, N.; Kiani, C.D.; Nehzati, S.; Tanoi, K.; et al. PIN FORMED 2 Modulates the Transport of Arsenite in Arabidopsis thaliana. Plant Comm. 2020, 1, 100009. [CrossRef]

15. Verma, P.K.; Verma, S.; Tripathi, R.D.; Chakrabarty, D. A rice glutaredoxin regulate the expression of aquaporin genes and modulate root responses to provide arsenic tolerance. Ecotoxico. Environ. Saf. 2020, 195, 110471. [CrossRef]

16. Yamaji, N.; Ma, J.F. The node, a hub for mineral nutrient distribution in graminaceous plants. Trends Plant Sci. 2014, 19, 556-563. [CrossRef] [PubMed]

17. Song, W.Y.; Yamaki, T.; Yamaji, N.; Ko, D.H.; Jung, K.H.; Fujii-Kashino, M.; An, G.; Martinoia, E.; Lee, Y.; Ma, J.F. A rice ABC transporter, OsABCC1, reduces arsenic accumulation in the grain. Proc. Natl. Acad. Sci. USA 2014, 111, 15699-15704. [CrossRef] [PubMed]

18. Okada, M.; Hamasaki, T.; Hayashi, T. Temperature gradient chambers for research on global environment change. I. Thermal environment in a large chamber. Biotronics 1995, 24, 85-97.

19. Matsumoto, S.; Kasuga, J.; Taiki, N.; Makino, T.; Arao, T. Reduction of the risk of arsenic accumulation in rice by the water management and material application in relation to phosphate status. J. Plant Interact. 2015, 10, 65-74. [CrossRef]

20. Li, R.Y.; Stroud, J.L.; Ma, J.F.; Mcgrath, S.P.; Zhao, F.J. Mitigation of arsenic accumulation in rice with water management and silicon fertilization. Environ. Sci. Technol. 2009, 43, 3778-3783. [CrossRef]

21. Zhao, F.J.; McGrath, S.P.; Meharg, A.A. Arsenic as a Food Chain Contaminant: Mechanisms of Plant Uptake and Metabolism and Mitigation Strategies. Annu. Rev. Plant Biol. 2010, 61, 535-559. [CrossRef]

22. Matsumoto, S.; Kasuga, J.; Taiki, N.; Makino, T.; Arao, T. Inhibition of arsenic accumulation in Japanese rice by the application of iron and silicate materials. Catena 2015, 135, 328-335. [CrossRef]

23. Matumoto, S.; Kasuga, J.; Makino, T.; Arao, T. Evaluation of the effects of application of iron materials on the accumulation and speciation of arsenic in rice grain grown on uncontaminated soil with relatively high levels of arsenic. Environ. Exp. Bot. 2016, 125, 42-51. [CrossRef]

24. Tao, F.; Hayashi, Y.; Zhang, Z.; Sakamoto, T.; Yokozawa, M. Global warming, rice production, and water use in China: Developing a probabilistic assessment. Agric. For. Meteorol. 2008, 148, 94-110. [CrossRef]

25. Van Kiet, H.; Nose, A. Effects of temperature on growth and photosynthesis in the seedling stage of the sheath blight-resistant rice genotype 32R. Plant Prod. Sci. 2016, 19, 246-256. [CrossRef]

26. Horie, T.; Baker, J.T.; Nakagawa, H.; Matsui, T.; Kim, H.Y. Crop ecosystem responses to climatic change: Rice. In Climate Change and Global Crop Productivity; CABI Publishing: Wallingford, UK, 2000; pp. 81-106.

27. Jin, Z.; Ge, D.; Chen, H.M.; Fang, J. Effects of climate change on rice production and strategies for adaptation in southern China. In Climate Change and Agriculture: Analysis of Potential International Impacts. Am. Soc. Agron. 1995, 59, 307-323.

28. Morita, S.; Wada, H.; Matsue, Y. Countermeasures for heat damage in rice grain quality under climate change. Plant Prod. Sci. 2016, 19, 1-11. [CrossRef]

29. Agostinho, F.B.; Tubana, B.S.; Martins, M.S.; Datnoff, L.E. Effect of different silicon sources on yield and silicon uptake of rice grown under varying phosphorus rates. Plants 2017, 6, 35. [CrossRef] 
30. Matoh, T.; Murata, S.; Takahashi, E. Effect of silicate application on photosynthesis of rice. Jpn. J. Soil Sci. Plant Nutr. 1991, 62, 248-251, (In Japanese with English summary).

31. Ando, H.; Kakuda, K.I.; Fujii, H.; Suzuki, K.; Ajiki, T. Growth and canopy structure of rice plants grown under field conditions as affected by si application. Soil Sci. Plant Nutr. 2002, 48, 429-432. [CrossRef]

32. Fujii, H.; Mori, S.; Ando, H. Effects of silicate fertilizer application on the yield of rice plants grown under insufficient light condition. Jpn. J. Soil Sci. Plant Nutr. 2008, 79, 471-477, (In Japanese with English summary).

33. Kaneta, Y.; Takahashi, D.; Sakaguchi, H.; Kon, K.; Takakai, F.; Sato, T. Effect of silicate fertilizer on leaf temperature, stoma conductance and silicic acid uptake in rice under high temperature during the ripening stage. Jpn. J. Sci. Soil Manure 2010, 81, 504-507. (In Japanese)

34. Mori, S.; Fujii, H. Utilization and research of silicon in recent agriculture: 6 . Alleviative effects of silicate application on the rice production by meteorlogical disaster. Jpn J. Soil Sci. Plant Nutr. 2013, 84, 504-507. (In Japanese)

35. Neumann, R.B.; Seyfferth, A.L.; Teshera-Levye, J.; Ellingson, J. Soil Warming Increases Arsenic Availability in the Rice Rhizosphere. Agric. Environ. Lett. 2017, 2, 170006. [CrossRef]

36. Weber, F.A.; Hofacker, A.F.; Voegelin, A.; Kretzschmar, R. Temperature dependence and coupling of iron and arsenic reduction and release during flooding of a contaminated soil. Environ. Sci. Technol. 2010, 44, 116-122. [CrossRef] [PubMed]

37. Tyrovola, K.; Nikolaidis, N.P. Arsenic mobility and stabilization in topsoils. Water Res. 2009, 43, $1589-1596$. [CrossRef] [PubMed]

38. Bogdan, K.; Schenk, M.K. Arsenic in rice (Oryza sativa L.) related to dynamics of arsenic and silicic acid in paddy soils. Environ. Sci. Technol. 2008, 42, 7885-7890. [CrossRef] [PubMed]

39. Li, G.; Zenng, M.; Tang, J.; Shim, H.; Cai, C. Effect of Silicon on Arsenic Concentration and Speciation in Different Rice Tissues. Pedosphere 2018, 28, 511-520. [CrossRef]

40. Wang, H.Y.; Wen, S.L.; Chen, P.; Zhang, L.; Cen, K.; Sun, G.X. Mitigation of cadmium and arsenic in rice grain by applying different silicon fertilizers in contaminated fields. Environ. Sci. Pollut. Res. 2016, 23, 3781-3788. [CrossRef]

41. Swedlundi, P.J.; Webester, J.G. Adsorption and polymerization of silicic acid on ferrihydrite, and its effect on arsenic adsorption. Water Res. 1999, 33, 3413-3422. [CrossRef]

42. Waltham, C.A.; Eick, M.J. Kinetics of Arsenic Adsorption on Goethite in the Presence of Sorbed Silicic Acid. Soil Sci. Soc. Am. J. 2002, 66, 818-825. [CrossRef]

43. Luxton, T.P.; Tadanier, C.J.; Eick, M.J. Mobilization of Arsenite by Competitive Interaction with Silicic Acid. Soil Sci. Soc. Am. J. 2006, 70, 204-214. [CrossRef]

44. Makino, T.; Nakamura, K.; Katou, H.; Ishikawa, S.; Ito, M.; Honma, T.; Miyazaki, N.; Takehisa, K.; Sano, S.; Matsumoto, S.; et al. Simultaneous decrease of arsenic and cadmium in rice (Oryza sativa L.) plants cultivated under submerged field conditions by the application of iron. Soil Sci. Plant Nutri. 2016, 62, 340-348. [CrossRef]

45. Ma, J.F.; Yamaji, N.; Mitani, N.; Xu, X.Y.; Su, Y.H.; McGrath, S.P.; Zhao, F.J. Transporters of arsenite in rice and their role in arsenic accumulation in rice grain. Proc. Natl. Acad. Sci. USA 2008, 105, 9931-9935. [CrossRef] [PubMed]

46. Ma, J.F.; Yamaji, N. Silicon uptake and accumulation in higher plants. Trends Plant Sci. 2006, 11, $392-397$. [CrossRef] [PubMed]

47. Ma, J.F.; Yamaji, N.; Mitani, N.; Tamai, K.; Konishi, S.; Fujiwara, T.; Katsuhara, M.; Yano, M. An efflux transporter of silicon in rice. Nature 2007, 448, 209-212. [CrossRef] [PubMed]

48. Kim, J.; Shon, J.; Lee, C.K.; Yang, W.; Yoon, Y.; Yang, W.H.; Kim, Y.G.; Lee, B.W. Relationship between grain filling duration and leaf senescence of temperate rice under high temperature. Field Crop. Res. 2011, 122, 207-213. [CrossRef]

(C) 2020 by the authors. Licensee MDPI, Basel, Switzerland. This article is an open access article distributed under the terms and conditions of the Creative Commons Attribution (CC BY) license (http://creativecommons.org/licenses/by/4.0/). 